\title{
Do consumers value food products containing upcycled ingredients? The effect of nutritional and environmental information
}

Article

Accepted Version

Creative Commons: Attribution-Noncommercial-No Derivative Works 4.0

Asioli, D. ORCID: https://orcid.org/0000-0003-2274-8450 and Grasso, S. (2021) Do consumers value food products containing upcycled ingredients? The effect of nutritional and environmental information. Food Quality and Preference, 91. 104194. ISSN 0950-3293 doi:

https://doi.org/10.1016/j.foodqual.2021.104194 Available at https://centaur.reading.ac.uk/95928/

It is advisable to refer to the publisher's version if you intend to cite from the work. See Guidance on citing.

Published version at: https://doi.org/10.1016/j.foodqual.2021.104194

To link to this article DOI: http://dx.doi.org/10.1016/j.foodqual.2021.104194

Publisher: Elsevier

All outputs in CentAUR are protected by Intellectual Property Rights law, including copyright law. Copyright and IPR is retained by the creators or other copyright holders. Terms and conditions for use of this material are defined in the End User Agreement. 


\section{www.reading.ac.uk/centaur}

\section{CentAUR}

Central Archive at the University of Reading

Reading's research outputs online 


\section{Journal Pre-proofs}

Short Communication

Do Consumers Value Food Products Containing Upcycled Ingredients? The Effect of Nutritional and Environmental Information

Daniele Asioli, Simona Grasso

PII:

S0950-3293(21)00021-5

DOI: https://doi.org/10.1016/j.foodqual.2021.104194

Reference:

To appear in:

Received Date:

Revised Date:

Accepted Date:

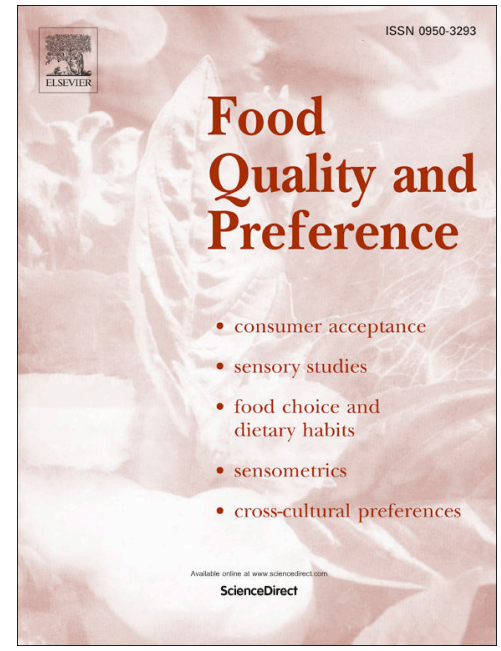

Please cite this article as: Asioli, D., Grasso, S., Do Consumers Value Food Products Containing Upcycled Ingredients? The Effect of Nutritional and Environmental Information, Food Quality and Preference (2021), doi: https://doi.org/10.1016/j.foodqual.2021.104194

This is a PDF file of an article that has undergone enhancements after acceptance, such as the addition of a cover page and metadata, and formatting for readability, but it is not yet the definitive version of record. This version will undergo additional copyediting, typesetting and review before it is published in its final form, but we are providing this version to give early visibility of the article. Please note that, during the production process, errors may be discovered which could affect the content, and all legal disclaimers that apply to the journal pertain.

(C) 2021 Elsevier Ltd. All rights reserved. 
${ }^{a}$ Department of Applied Economics and Marketing, School of Agriculture Policy and Development, University of Reading, Reading, United Kingdom.

${ }^{\mathrm{b}}$ Institute of Food, Nutrition and Health, University of Reading, Reading, United Kingdom.

* Corresponding author.

\begin{abstract}
This study was the first to use a ranking experiment to estimate the effect of nutritional and environmental information on UK consumers' willingness to pay (WTP) for biscuits containing an upcycled ingredient, namely, defatted sunflower cake flour. Informing consumers about the nutritional and/or environmental benefits of the upcycled ingredient resulted in a significant increase in their WTP for this new food. Moreover, we found that nutritional and/or environmental information similarly affected individual WTP distributions for the upcycled ingredient towards more positive values. Our findings have important implications for product development and marketing strategies of upcycled food businesses.
\end{abstract}

Keywords: Biscuits; Environmental information; Nutritional information; United Kingdom; Upcycled ingredients; Willingness to pay.

\title{
1. INTRODUCTION
}

About one-third, or 1.3 billion tons, of the total food produced for human consumption is lost or wasted globally every year (FAO, 2015). Food loss, that is, loss of food at the production, postharvest, and processing stages, can be reduced in various ways. One way is to upcycle food byproducts into valuable ingredients that can be used in the development of novel foods (i.e., upcycled foods) rather than used as feed or sources of energy (Spratt et al., 2020). Upcycled foods can provide several environmental (Augustin et al., 2020) and nutritional benefits, as food industry by-products are rich in valuable compounds, such as proteins, fibres, etc. (Trigo et al., 2020). An example is sunflower seed oilcake, a by-product of sunflower oil production, which contains high levels of proteins, fibres, vitamins, and minerals. It can be treated to become a food-grade high-protein flour that can be used in bakery and meat products in which it has already been tested successfully (Grasso et al., 2020).

However, several financial, policy, and communication issues must be resolved if upcycled foods are to become mainstream products. First, for financial reasons, the food industry is reluctant to invest in circular initiatives, as wasting by-products is in many cases economically more advantageous than saving them (May \& Guenther, 2020). Second, a common definition of upcycled foods was until very recently lacking, which created uncertainty (Spratt et al., 2020). Third, there is a lack of market data, consumer studies, and specific labelling regulations regarding upcycled foods. Indeed, very few studies have investigated consumers' preferences for upcycled foods (see Grasso \& Asioli, 2020 for a short review). Little research has been conducted to better understand how to position upcycled foods in the market and how to communicate their benefits to consumers (McCarthy et al., 2020). Recently, Zhang et al. (2020) found that consumers have high intentions to purchase upcycled foods and that as the perceived quality of these foods decrease also consumers' intention to purchase also decrease. They also found that Gen X shows lower intentions to purchase upcycled foods compared to Gen Z, Gen Y, and Baby Boomers because of the perceived lower quality. Zhang et al. (2020) also suggest that to increase consumers' willingness to buy for upcycled 
foods it is necessary to assure consumers about the quality and benefits of such foods. A positive quality perception can be created by providing messages that highlight the quality of upcycled foods (Zhang et al. 2020) by using intrinsic and extrinsic cues around these new products that drive consumers' acceptance and that can be leveraged by marketers. Indeed, recent research demonstrates that consumers' acceptance of upcycled foods can be shaped by appropriately communicating the value of consuming these new foods (Bhatt et al., 2020). Furthermore, consumers' willingness to pay (WTP) studies for upcycled foods show important results. Grasso and Asioli (2020) showed that without providing information on benefits consumers reject upcycled biscuits. Köpcke (2020) found that by informing consumers that upcycled foods can reduce food loss they are willing to pay the same or a premium price compared to conventional foods while Bhatt et al. (2020) found that rational messaging is more effective than emotional messaging in increasing consumers' WTP for upcycled foods. However, it remains unknown whether other rational messages around nutritional or other environmental benefits might be more persuasive and could be successfully communicated to consumers.

This study aimed to fill this by conducting a hypothetical ranking experiment (RE) to estimate the effect of nutritional and/or environmental information on UK consumers' WTP for biscuits containing upcycled defatted sunflower oilcake flour (hereafter "upcycled biscuits"). Nutritional (higher protein content) and environmental (lower carbon footprint) messages were chosen as intrinsic and extrinsic cues, respectively, as they were considered the most likely to raise consumers' WTP. An increased emphasis on nutrition and environmental information has been shown to drive consumers' food purchases as Banovic et al. (2018) for nutritional information related to protein content in foods and Asioli et al. (2020) for environmental information related to food production demonstrate. Furthermore, nutritional, and environmental information are two different types of rational messages that can have different effects on consumers' acceptance of new foods. For example, Annett et al. (2008) found that health information had an impact on consumers' preferences for organic bread, whereas environmental information about organic production did not.

\section{MATERIALS AND METHODS}

\subsection{Experimental design}

To test our research hypotheses, we implemented a between-subjects design based on four RE treatments. The four treatments differed only in the kind of information provided prior to starting the series of choice tasks. Each participant was randomly assigned to only one of the RE treatments. In treatment 1, called "no information (NOINFO)", 106 participants were not provided with information on upcycled biscuits' benefits. In treatment 2, called "nutritional information (NUTINFO)", 108 respondents were provided with nutritional information stating that the upcycled ingredient increased the biscuits' protein content. In treatment 3, called "environmental information (ENVINFO)", 108 respondents were provided with environmental information stating that the upcycled ingredient reduced the biscuits' carbon footprint. Finally, in treatment 4, called "nutritional and environmental information (NUENINFO)", 108 participants were provided with both nutritional and environmental information.

With these RE treatments, we constructed a series of hypotheses to examine whether the information about the benefits of the upcycled ingredient would affect respondents' WTP for the biscuits. To determine the effect of the different types of information, we compared the estimates from the four treatments. Specifically, we performed the following six comparisons:

- $\quad$ Treatment 1 (NOINFO) vs treatment 2 (NUTINFO). The hypotheses to test whether nutritional information would affect respondents' WTP were as follows:

$$
\begin{aligned}
& \mathrm{H}_{01}: \mathrm{WTP}^{\text {NUTINFO }}-\mathrm{WTP}^{\text {NOINFO }} \leq 0 \\
& \mathrm{H}_{11}: \mathrm{WTP}^{\text {NUTINFO }}-\mathrm{WTP}^{\text {NOINFO }}>0
\end{aligned}
$$


A rejection of the null hypothesis $\left(\mathrm{H}_{01}\right)$ would indicate that nutritional information was more effective than no information.

- Treatment 1 (NOINFO) vs treatment 3 (ENVINFO). The hypotheses to test whether environmental information would affect respondents' WTP were as follows:

$$
\begin{aligned}
& \mathrm{H}_{02}: \mathrm{WTP}^{\mathrm{ENVINFO}}-\mathrm{WTP}^{\text {NOINFO }} \leq 0 \\
& \mathrm{H}_{12}: \mathrm{WTP}^{\mathrm{ENVINFO}}-\mathrm{WTP}^{\text {NOINFO }}>0
\end{aligned}
$$

A rejection of the null hypothesis $\left(\mathrm{H}_{02}\right)$ would indicate that environmental information was more effective than no information.

- Treatment 1 (NOINFO) vs treatment 4 (NUENINFO). The hypotheses to test whether both nutritional and environmental information would affect respondents' WTP were as follows:

$$
\begin{aligned}
& \mathrm{H}_{03}: \text { WTPNUENINFO }-\mathrm{WTP}^{\text {NOINFO }} \leq 0 \\
& \mathrm{H}_{13}: \mathrm{WTP}^{\text {NUENINFO }}-\mathrm{WTP}^{\text {NOINFO }}>0
\end{aligned}
$$

A rejection of the null hypothesis $\left(\mathrm{H}_{03}\right)$ would indicate that both nutritional and environmental information was more effective than no information.

- Treatment 2 (NUTINFO) vs treatment 3 (ENVINFO). The hypotheses to test whether environmental information would be more effective than nutritional information was as follows:

$$
\begin{aligned}
& \mathrm{H}_{04}: \mathrm{WTP}^{\mathrm{ENVINFO}}-\mathrm{WTP}^{\mathrm{NUTINFO}} \leq 0 \\
& \mathrm{H}_{14}: \mathrm{WTP}^{\mathrm{ENVINFO}}-\mathrm{WTP}^{\mathrm{NUTINFO}}>0
\end{aligned}
$$

A rejection of the null hypothesis $\left(\mathrm{H}_{04}\right)$ would indicate that environmental information was more effective than nutritional information.

- Treatment 2 (NUTINFO) vs treatment 4 (NUENINFO). The hypotheses to test whether a combination of nutritional and environmental information would be more effective than nutritional information only was as follows:

$$
\begin{aligned}
& \mathrm{H}_{05}: \mathrm{WTP}^{\text {NUENINFO }}-\mathrm{WTP}^{\mathrm{NUTINFO}} \leq 0 \\
& \mathrm{H}_{15}: \mathrm{WTP}^{\mathrm{NUENINFO}}-\mathrm{WTP}^{\text {NUTINFO }}>0
\end{aligned}
$$

A rejection of the null hypothesis $\left(\mathrm{H}_{05}\right)$ would indicate that a combination of nutritional and environmental information was more effective than nutritional information only.

- Treatment 3 (ENVINFO) vs treatment 4 (NUENINFO). The hypotheses to test whether a combination of nutritional and environmental information would be more effective than environmental information only was as follows:

$$
\begin{aligned}
& \mathrm{H}_{06}: \mathrm{WTP}^{\text {NUENINFO }}-\mathrm{WTP} \text { ENVINFO } \leq 0 \\
& \mathrm{H}_{16}: \mathrm{WTP}^{\mathrm{N} U E N I N F O}-\mathrm{WTP} \text { ENVINFO }>0
\end{aligned}
$$

A rejection of the null hypothesis $\left(\mathrm{H}_{06}\right)$ would indicate that a combination of nutritional and environmental information was more effective than environmental information only.

In the RE, we included four attributes with two levels each to describe the different types of biscuits: "flour", "protein", "carbon", and "price" (for more details, see Grasso \& Asioli, 2020). Two price levels were specified to approximately reflect the lower and upper market prices $(£ 0.40 / 300 \mathrm{~g}$ and $£ 1.50 / 300 \mathrm{~g}$, respectively) of a typical 300 -g pack of biscuits sold in UK stores.

To ease the participants' cognitive burden, the ranking was conducted as a series of choices over seven screens (for more details, see Grasso \& Asioli, 2020). A pre-test involving fifty participants was performed to calibrate the minimum time needed by them to complete the questionnaire and to test whether the survey flow (i.e., skip logic) and questions were appropriate to ensure good data quality.

A description of the entire experiment, including information on participant recruitment, experimental design, and attributes and levels, is provided in Grasso and Asioli (2020). 


\subsection{Data}

The randomization of consumers to the four treatments aimed to achieve a balance of observable characteristics across the treatments. Indeed, the results showed that the hypothesis of equality of means of sociodemographic characteristics across treatments was not rejected at a 5\% significance level (results not shown). Hence, the random assignment of respondents to the treatments provided a balanced sample in terms of sociodemographic characteristics across the four treatments.

\section{ECONOMETRIC ANALYSIS}

To test our hypotheses, we used discrete choice models (DCMs) typically applied to analyse ranking and choice data (Hensher et al., 2015). We followed the approach used by Øvrum et al. (2012) which assumes that ranking options are formally equivalent to being able to choose the most preferred option from a set of options, then the second-best, third best and so on, until the least preferred option is identified. Thus, for each consumer the ranking data of eight biscuits is converted into a series of seven choice sets of reduced size of options (biscuits) such as eight, seven, six, five, four, three, and two biscuits, respectively in each choice set. The first-choice set includes all eight biscuits, and the participant chooses the biscuit that he or she ranked highest in the experiment. The second-choice set includes all eight biscuits minus his or her highest ranked biscuit, and so on until the seven-choice sets. Data can be analysed using the rank-ordered mixed logit (ROML) or the standard mixed logit (ML) models and we obtained similar results. To test the differences in WTP between the four treatments involved in our hypotheses using the estimated coefficients, we calculated the marginal WTP (mWTP) in preference space using mixed logit (ML) models (for more details, see Grasso \& Asioli, 2020) across the four treatments as a ratio of the partial derivative of the utility function with respect to the design attribute of interest and then divided it by the partial derivative of the utility function with respect to the price variable. The WTP of each attribute level was obtained using Krinsky and Robb's (1986) bootstrapping method, resulting in a distribution of 1,000 WTP values for each attribute. These WTP estimates were then used to test our hypotheses using the computational method proposed by Poe et al. (2005). The Poe et al.'s test was performed using the STATA 16.0 module poetest to obtain the significance levels.

Next, we investigated consumers' heterogeneity by calculating the distribution of the individuallevel coefficients (i.e. mWTP) for flour, protein, and carbon using the kernel density estimation across individuals with the kdensity command in STATA 16.0.

\section{RESULTS}

\subsection{WTP estimates: Effect of nutritional and environmental information}

The WTP preference space estimation results for the four treatments obtained by the ML models are shown in Table 1. Specifically, the estimated WTP for flour, protein, and carbon and the corresponding confidence intervals (95\% confidence intervals) are reported. On average, respondents were willing to pay higher prices for biscuits that were branded as a "source of protein" and labelled with the "Carbon Trust label". Upcycled sunflower flour was preferred over conventional wheat flour only if information on the nutritional and/or environmental benefits of upcycled biscuits had been provided.

Table 1 - WTP in preference space for the four treatments estimated using the mixed logit models.

\begin{tabular}{|c|c|c|c|c|c|c|c|c|}
\hline \multirow{2}{*}{ Attribute } & \multicolumn{2}{|c|}{$\begin{array}{l}\text { NOINFO } \\
(N=106)\end{array}$} & \multicolumn{2}{|c|}{$\begin{array}{c}\text { NUTINFO } \\
(N=108)\end{array}$} & \multicolumn{2}{|c|}{$\begin{array}{c}\text { ENVINFO } \\
(N=108)\end{array}$} & \multicolumn{2}{|c|}{$\begin{array}{l}\text { NUENVINFO } \\
\quad(N=108)\end{array}$} \\
\hline & WTP & $95 \%$ CI & WTP & 95\% CI & WTP & $95 \%$ CI & WTP & $95 \%$ CI \\
\hline
\end{tabular}




\begin{tabular}{|c|c|c|c|c|c|c|c|c|}
\hline & $(\mathfrak{f} / 300 \mathrm{~g})$ & & $(\mathfrak{f} / 300 \mathrm{~g})$ & & $(£ / 300 \mathrm{~g})$ & & $(£ / 300 \mathrm{~g})$ & \\
\hline Flour & -0.28 & $-0.44,-0.11$ & 0.16 & $0.02,0.29$ & 0.09 & $-0.16,0.33$ & 0.25 & $0.12,0.39$ \\
\hline Protein & 0.34 & $0.20,0.48$ & 0.29 & $0.19,0.39$ & 0.27 & $0.13,0.41$ & 0.28 & $0.19,0.37$ \\
\hline Carbon & 0.60 & $0.44,0.77$ & 0.38 & $0.25,0.51$ & 0.47 & $0.31,0.63$ & 0.44 & $0.34,0.53$ \\
\hline
\end{tabular}

Note. WTP: willingness to pay.

Note. CI: confidence interval.

Note. The dataset used for the calculation of the WTPs in the NOINFO treatment is the same used in Grasso \& Asioli (2020).

Table 2 reports the participants' WTP for each treatment for flour, protein, and carbon and the corresponding significance levels ( $p$-values) calculated by the Poe test. Since the main aim of this research was to test the effect of information on consumers' WTP for flour, only the results related to flour are described here. The first null hypothesis $\left(\mathrm{H}_{01}\right.$ : WTPNUTINFO - WTP $\left.^{\mathrm{NOINFO}} \leq 0\right)$ was rejected; thus, the alternative hypothesis was accepted: the WTP will be higher when consumers are provided with information about nutritional benefits compared to when such information is not provided. The second null hypothesis $\left(\mathrm{H}_{02}\right.$ : WTPENVINFO - WTPNOINFO $\left.\leq 0\right)$ was also rejected, and the alternative hypothesis was accepted: the WTP will be higher when consumers are provided with information about environmental benefits compared to when such information is not provided. The third null hypothesis $\left(\mathrm{H}_{03}\right.$ : WTPNUENINFO - WTPNOINFO $\left.\leq 0\right)$ was also rejected, and therefore the alternative hypothesis was accepted: the WTP will be higher when consumers are provided with information about both nutritional and environmental benefits compared to when such information is not provided. The fourth null hypothesis $\left(\mathrm{H}_{04}\right.$ : WTPENVINFO - WTPNUTINFO $\left.\leq 0\right)$ was accepted, and thus the alternative hypothesis was rejected: WTP will not be higher when consumers are provided with information about environmental benefits compared to when they were provided with nutritional information. The fifth null hypothesis $\left(\mathrm{H}_{05}\right.$ : WTP $\left.{ }^{\mathrm{NUENINFO}}-\mathrm{WTP}^{\mathrm{NUTINFO}} \leq 0\right)$ was also accepted, and the alternative hypothesis was rejected: WTP will not be higher when consumers are provided with information about both nutritional and environmental benefits compared to when they were provided with nutritional information only. Finally, the sixth null hypothesis $\left(\mathrm{H}_{06}\right.$ : WTPNUENINFO - WTPENVINFO $\leq 0$ ) was also accepted, and therefore the alternative hypothesis was rejected: the WTP will not be higher when consumers are provided with information about both nutritional and environmental benefits compared to when they were provided with environmental information only.

Table 2 - Marginal WTP (£/300 g) across four treatments and hypothesis tests.

\begin{tabular}{|c|c|c|c|c|c|c|}
\hline \multirow[b]{2}{*}{ Hypothesis test (Poe test) } & \multicolumn{2}{|c|}{ FLOUR } & \multicolumn{2}{|c|}{ PROTEIN } & \multicolumn{2}{|c|}{ CARBON } \\
\hline & $\begin{array}{l}\text { WTP: } \\
\mathfrak{f} / 300 \mathrm{~g}\end{array}$ & p-value & $\begin{array}{l}\text { WTP: } \\
\mathfrak{f} / 300 \mathrm{~g}\end{array}$ & p-value & $\begin{array}{l}\text { WTP: } \\
\mathfrak{f} / \mathbf{3 0 0 \mathrm { g }}\end{array}$ & p-value \\
\hline $\mathrm{H}_{01}: \mathrm{WTP}^{\mathrm{NUTINFO}}-\mathrm{WTP}^{\mathrm{NOINFO}} \leq 0$ & & & & & & \\
\hline $\begin{array}{l}\text { WTP }{ }^{\text {NUTINFO }} \\
\text { WTP }^{\text {NOINFO }}\end{array}$ & $\begin{array}{c}0.16 \\
-0.28\end{array}$ & 0.00 & $\begin{array}{l}0.29 \\
0.34\end{array}$ & 0.71 & $\begin{array}{l}0.38 \\
0.60\end{array}$ & 0.99 \\
\hline 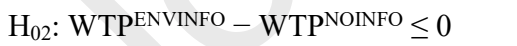 & & & & & & \\
\hline $\begin{array}{l}\text { WTPENVINFO } \\
\text { WTP } \\
\text { NOINFO }\end{array}$ & $\begin{array}{c}0.09 \\
-0.28\end{array}$ & 0.01 & $\begin{array}{l}0.27 \\
0.34\end{array}$ & 0.74 & $\begin{array}{l}0.47 \\
0.60\end{array}$ & 0.88 \\
\hline $\begin{array}{l}\mathrm{H}_{03}: \\
\text { WTPNUTENVINFO }- \text { WTP }^{\text {NOINFO }} \leq 0 \\
\text { WTP } \\
\text { WTUTENVINFO } \\
\text { WTOINFO }\end{array}$ & $\begin{array}{c}0.25 \\
-0.28\end{array}$ & 0.00 & $\begin{array}{l}0.28 \\
0.34\end{array}$ & 0.75 & $\begin{array}{l}0.44 \\
0.60\end{array}$ & 0.97 \\
\hline $\begin{aligned} \mathrm{H}_{04}: & \text { WTPENVINFO }- \text { WTPNUTINFO } \leq 0 \\
& \text { WTPENVINFO } \\
& \text { WTP } \\
& \text { NUTINFO }\end{aligned}$ & $\begin{array}{l}0.09 \\
0.16\end{array}$ & 0.68 & $\begin{array}{l}0.27 \\
0.29\end{array}$ & 0.56 & $\begin{array}{l}0.47 \\
0.38\end{array}$ & 0.19 \\
\hline $\begin{aligned} & \mathrm{H}_{05}: \text { WTPNUTENVINFO }-\mathrm{WTP}^{\text {NUTINFO }} \leq 0 \\
& \text { WTPNUTENVINFO } \\
& \text { WTP } \\
& \text { WUTINFO }^{\text {NTI }}\end{aligned}$ & $\begin{array}{l}0.25 \\
0.16\end{array}$ & 0.18 & $\begin{array}{l}0.28 \\
0.29\end{array}$ & 0.54 & $\begin{array}{l}0.44 \\
0.38\end{array}$ & 0.25 \\
\hline $\begin{aligned} & \mathrm{H}_{06}: \text { WTPNUTENVINFO }- \text { WTPENVINFO }^{\text {WTO }} \leq 0 \\
& \text { WTPNUTENVINFO } \\
& \text { WTP } \\
&\end{aligned}$ & $\begin{array}{l}0.25 \\
0.09\end{array}$ & 0.15 & $\begin{array}{l}0.28 \\
0.27\end{array}$ & 0.45 & $\begin{array}{l}0.44 \\
0.47\end{array}$ & 0.65 \\
\hline
\end{tabular}


Note. WTP: willingness to pay.

Note. The dataset used for the calculation of the WTPNOINFO is the same used in Grasso \& Asioli (2020).

\subsection{WTP estimates: Distribution of individual $m W T P$ values}

Fig. 1 presents the distributions of mWTP values across individuals (kernel density estimates) for the attributes flour, protein, and carbon across the different information treatments. Not only did the mean values for each mWTP differ, but some mWTP distributions were considerably more diffuse (i.e., heterogeneous) than others. Specifically, the probability density functions for flour were similarly and heterogeneously distributed across the treatments, but the mWTP tended to move towards more positive values when nutritional and/or environmental information was provided. Furthermore, there were important differences in the distributions of the mWTP for the attributes protein and carbon when comparing NUTINFO, ENVINFO and NUENINFO with NOINFO. Indeed, for the protein attribute when nutritional or environmental information was provided separately consumers valued more similarly (i.e., homogeneously) this information (similar mWTP) thus one homogenous consumer segment could be identified. Differently, for protein when both nutritional and environmental information was provided together consumers valued this information more dissimilarly (i.e., heterogeneously) thus two or more consumer segments could be identified. Furthermore, for the carbon attribute when both nutritional and environmental information or environmental information only was provided consumers valued more similarly this information, thus one homogenous consumer segment could be identified while when nutritional information only was provided consumers valued this information more dissimilarly (i.e., heterogeneously), thus two or more consumer segments could be identified. 


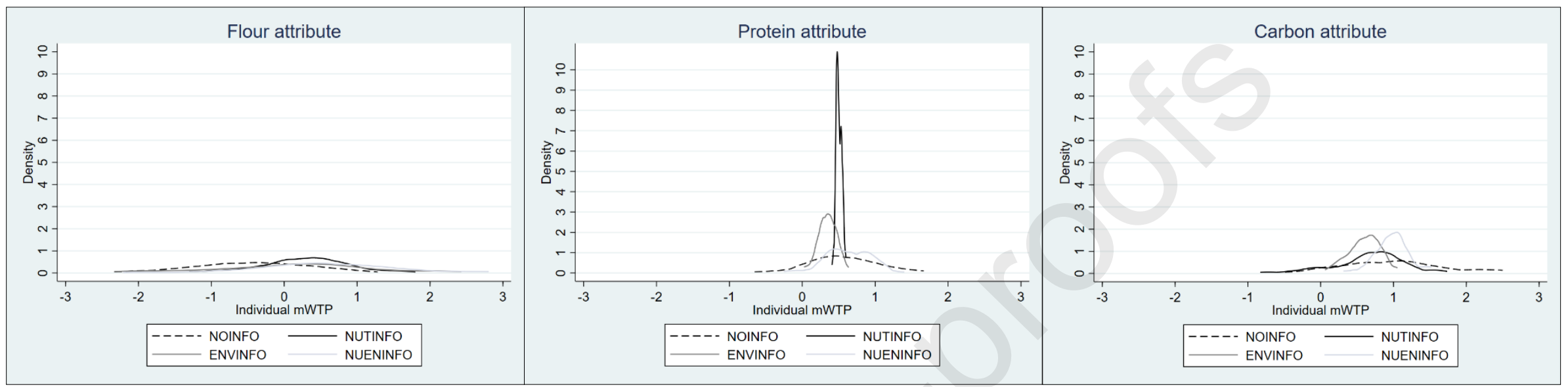

of individual mWTP for the attributes: flour, protein, and carbon across the NOINFO treatment and each information treatment (NUTINFO, ENVINFO, and NUENINFO). 


\section{DISCUSSION AND CONCLUSIONS}

This study investigated UK consumers' WTP for hypothetical upcycled biscuits by exploring the effect of nutritional and/or environmental information about the benefits of upcycled ingredients. Three main results were obtained. First, when nutritional and/or environmental information about the benefits of the upcycled biscuits was provided, participants' were willing to pay a premium price compared to when such information was not provided. This finding is consistent with those of Bhatt et al. (2020), and Cattaneo et al. (2019). Similarly to our environmental treatment, our results are corroborated by Köpcke (2020) who found that consumers are willing to pay the same or a premium price if they are informed that upcycled foods can reduce food loss. Moreover, as suggested by Zhang et al. (2020), we found that by informing consumers about the benefits (i.e. nutritional and environmental) of upcycled foods increases consumers' WTP for these foods. Second, the effect of providing environmental information was comparable to that of providing nutritional or both nutritional and environmental information. We speculate that although nutrition is more important than environmental concerns in driving food choices (Lusk \& Briggeman, 2009), consumers may associate upcycled foods more with the environmental benefits of reducing food loss and waste than with nutritional benefits. This may have counterbalanced the hypothetical stronger effect of nutritional information on respondents' WTP. Third, we found that for flour the nutritional and/or environmental information similarly affected individual mWTP distribution across the treatments towards more positive WTP values, while for protein and carbon, the mWTP distributions differ depending on the type of information provided. This might eventually suggest that mWTP formation for flour, protein and carbon were differently affected by the kind of information provided indicating the existence of different consumers' segments that can be leveraged by different marketing strategies.

These findings have important implications for upcycled food businesses. Marketing campaigns that emphasize the nutritional and/or environmental benefits of these new foods can increase consumers' acceptance. Moreover, upcycled food businesses could use our findings regarding the mWTP to compare it with the production cost and suggest optimal prices of sales of upcycled foods to their clients (i.e. supermarkets). For policy makers, it seems important to work towards providing more information to broaden and deepen consumers' understanding of upcycled foods and increase their familiarity with them. Educating consumers might increase the demand for upcycled foods, which in turn might make producers more willing to produce such products.

Further research is needed to test the robustness of our findings and explore the market potential of upcycled foods. Similar studies should be conducted in other countries, conduct cross-country comparisons, and with other upcycled foods. Moreover, future studies could investigate consumers' WTP by conducting non-hypothetical experiments in real market contexts (e.g., shops) using auctions combined with sensory evaluations of upcycled foods to obtain more comprehensive and realistic results.

In conclusion, our findings show that consumers' WTP premium prices for upcycled foods depends on the provided information about the nutritional and/or environmental benefits of these new foods. Our results provide insights into consumers' acceptance psychology that can be useful for effectively communicating the benefits of upcycled foods to the public to maximize the chances of making them commercially viable.

\section{ACKNOWLEDGEMENTS}

The authors would like to thank Dr Julian Sagebiel for providing the STATA command poetest, which he wrote. 


\section{FUNDING}

This work was supported by a Food Pump Priming Award from the Research Dean for Food at the University of Reading [grant number E3630500].

\section{TRANSPARENT REPORTING}

Pre-registration of the study is available at https://aspredicted.org/blind.php? $\mathrm{x}=\mathrm{z} 7 \mathrm{cy} 6 \mathrm{~b}$.

\section{REFERENCES}

Annett, L. E., Muralidharan, V., Boxall, P. C., Cash, S. B., \& Wismer, W. V. (2008). Influence of health and environmental information on hedonic evaluation of organic and conventional bread. Journal of Food Science, 73(4), H50-H57.

Asioli, D., Aschemann-Witzel, J., \& Nayga, R. M. J. (2020). Sustainability-related food labels. Annual Review of Resource Economics, 12, 171-185.

Augustin, M. A., Sanguansri, L., Fox, E. M., Cobiac, L., \& Cole, M. B. (2020). Recovery of wasted fruit and vegetables for improving sustainable diets. Trends in Food Science \& Technology, 95, 75-85.

Banovic, M., Arvola, A., Pennanen, K., Duta, D. E., Brückner-Gühmann, M., Lähteenmäki, L., \& Grunert, K. G. (2018). Foods with increased protein content: A qualitative study on European consumer preferences and perceptions. Appetite, 125, 233-243.

Bhatt, S., Ye, H., Deutsch, J., Ayaz, H., \& Suri, R. (2020). Consumers' willingness to pay for upcycled foods. Food Quality and Preference, 86, 104035.

Cattaneo, C., Lavelli, V., Proserpio, C., Laureati, M., \& Pagliarini, E. (2019). Consumers' attitude towards food by-products: the influence of food technology neophobia, education and information. International Journal of Food Science \& Technology, 54(3), 679-687.

FAO. (2015). Global initiative on food loss and waste reduction.

Grasso, S., \& Asioli, D. (2020). Consumer preferences for upcycled ingredients: a case study with biscuits. Food Quality and Preference, 84(September), 103951.

Grasso, S., Pintado, T., Pérez-Jiménez, J., Ruiz-Capillas, C., \& Herrero, A. M. (2020). Potential of a sunflower seed by-product as animal fat replacer in healthier frankfurters. Foods, 9, 445.

Hensher, Rose, J. M., \& Green, W. (2015). Applied Choice Analysis (2nd ed.). Cambridge University Press.

Köpcke, J. (2020). From waste to premium: Consumers perception of value-added surplus products and their willingness to pay. http://essay.utwente.nl/85249/

Krinsky, I., \& Robb, A. L. (1986). On approximating the statistical properties of elasticities. The Review of Economics and Statistics, 68(4), 715-719.

Lusk, J., \& Briggeman, B. C. (2009). Food values. American Journal of Agricultural Economics, 91(1), 184-196.

May, N., \& Guenther, E. (2020). Shared benefit by material flow cost accounting in the food supply chain - The case of berry pomace as upcycled by-product of a black currant juice production. Journal of Cleaner Production, 245, 118946.

McCarthy, B., Kapetanaki, A. B., \& Wang, P. (2020). Completing the food waste management loop: Is there market potential for value-added surplus products (VASP)? Journal of Cleaner Production, 256, 120435.

Øvrum, A., Alfnes, F., Almli, V. L., \& Rickertsen, K. (2012). Health information and diet choices: Results from a cheese experiment. Food Policy, 37(5), 520-529.

Poe, G. L., Giraud, K. L., \& Loomis, J. B. (2005). Computational methods for measuring the difference of empirical distributions. American Journal of Agricultural Economics, 87(2), 353365. 
Spratt, O., Suri, R., \& Deutsch, J. (2020). Defining upcycled food products. Journal of Culinary Science \& Technology, 1-12.

Trigo, J. P., Alexandre, E. M. C., Saraiva, J. A., \& Pintado, M. E. (2020). High value-added compounds from fruit and vegetable by-products - Characterization, bioactivities, and application in the development of novel food products. Critical Reviews in Food Science and Nutrition, 60(8), 1388-1416.

Zhang, J., Ye, H., Bhatt, S., Jeong, H., Deutsch, J., Ayaz, H., \& Suri, R. (2020). Addressing food waste: How to position upcycled foods to different generations. Journal of Consumer Behaviour, $n / a(\mathrm{n} / \mathrm{a}), 1-9$.

\section{CREDIT AUTHORSHIP CONTRIBUTION STATEMENT}

Daniele Asioli: Methodology, Formal analysis, Software, Validation, Writing - original draft, Writing - review \& editing. Simona Grasso: Conceptualization, Investigation, Funding acquisition, Project administration, Writing - original draft, Writing - review \& editing.

\section{Declaration of interests}

区 The authors declare that they have no known competing financial interests or personal relationships that could have appeared to influence the work reported in this paper.

$\square$ The authors declare the following financial interests/personal relationships which may be considered as potential competing interests: 
376

377 HIGHLIGHTS

378 - $430 \mathrm{UK}$ consumers chose biscuits containing a conventional or an upcycled ingredient.

379 - Nutritional and environmental information of the upcycled ingredient were provided to

$380 \quad$ consumers.

381 - Nutritional and environmental information similarly increased consumers' WTP.

382 - Implications for upcycled food businesses and policy makers were provided.

383

384 